\title{
METHODOLOGY OF OPTIMUM SELECTION OF MATERIAL AND SEMI-FOLDED PRODUCTS FOR ROTORS OF OPEN-END SPINNING MACHINE
}

\author{
Stanisław Płonka1*, Jacek Postrożny², Robert Drobina ${ }^{3}$ \\ 1 Department of Manufacturing Technology and Automation, University of Bielsko-Biała, 43-309 Bielsko-Biała, ul. Willowa 2, Poland \\ 2 Institute of Management and Production Engineering, Cavalry Captain Witold Pilecki State University of Malopolska in Oświęcim, 32-600 Oświęcim, ul. M. \\ Kolbego 8, Poland, \\ 3 Faculty of Mechanical Engineering and Computer Science, University of Bielsko-Biała, 43-309 Bielsko-Biała, ul. Willowa 2, Poland, \\ *Corresponding author. E-mail: splonka@ath.bielsko.pl
}

\begin{abstract}
:
The article presents the methodology of optimal selection of material and the form of semi-product for the rotors of the spindle-less spinning machine. The multicriteria approach was utilized taking into account versatile criteria. The applied procedure consists of two stages: the optimum method in the Pareto sense and the method of distance function. Based on the analysis of the spinning head work, rotor and availability function, six different materials and three forms of semifinished products (extruded bar, forged element, and cast element) were considered. In consequence, the admissible set consisting of nine elements was obtained. For the evaluation of technological quality of the rotor, the following criteria were proposed: index of functionality of the material $\sigma_{f} / \rho$, maximum height of the surface peaks, $S p$, and maximal hardness on surface of oxide layer $\mu H V_{0,1}$. Finally, taking into account the economical criterion (unit cost), the Pareto-optimal set of solutions was determined based on four criteria. Due to the fact that this set contained five variants, the distance function was utilized for choosing the best final variant. The optimal material and the semi-product (because of the assumed criteria) chosen were as follows: alloy AlSi1MgMn and the forged element-because in this case the value of distance function was minimal.
\end{abstract}

\section{Keywords:}

Pareto optimum; manufacturing cost; technological quality; rotor of the open-end spinner

\section{Introduction}

In the textile industry, there are many ways of forming yarns and with each of them you can get a yarn with a unique structure and very good physical properties ensuring optimal production efficiency. The reference point is ring spinning enabling the production of yarns from a wide numbering range and number of twists. The disadvantage of the ring technique is the low production capacity. It usually forces manufacturers to design spinners equipped with a very large number of spindles, which is associated with vast production space occupied by these machines. Production of yarns using open-end technology can compete with ring spinning only in terms of economic benefits, but never in quality; rotor yarns have a limited range of applicability due to the limited range of linear density (15200) textile as well as the inferior properties resulting from the braids that are impossible to eliminate, which make the surface of the finished product more rough.

One of the most important problems in rotor spinning is choosing the right rotor diameter. This diameter depends on the length of the processed fibers. As a result of extensive research in recent spinner design solutions, the rotor diameters have been significantly reduced compared to previous versions. It is currently considered that the diameter of the rotors should have 0.9-1.1 average fiber length for spinners designed for spinning cotton-type fibers [1]. The correct choice of rotor diameter is complicated because it significantly affects the formation and breakage of the yarn during spinning process.
With reduced rotor diameter and at the same rotational speed, energy consumption, yarn tension and breakage are reduced. The open-end yarns produced with the reduced diameter of the rotors are characterized by poor structure and reduced strength. In addition, the requirements for uniformity and degree of cleaning of the feed sliver are increasing. At the same time, it becomes necessary to increase the twist factor as the number of breaks in the spinning process increases and hence the quality of the yarn deteriorates. The yarn produced on rotor spinners is characterized by a $10-15 \%$ reduced tensile strength compared to ring yarn, which, however, is largely compensated by greater evenness in the distribution of linear mass and strength, and greater elongation of the yarn.

The yarn from rotor spinners is characterized by lower hairiness, higher friction resistance, and better dyeability. Fabrics and knitted fabrics made of yarn produced on rotor spinning frames have a harder grip and a higher friction resistance. The properties of rotor spinning yarns largely depend on the individual design solutions of individual working nodes of these machines. The following phases can be distinguished in rotor spinning: thinning the sliver and creating a discontinuous fiber stream, transferring the discontinuous fiber stream to the free end zone of yarn, condensing the discontinuous fiber stream, twisting and forming the yarn by tightening, winding the yarn, and forming the package.

Twist in the rotor is a combination of the actual twist created by the rotation of the rotors and the temporary twist caused 


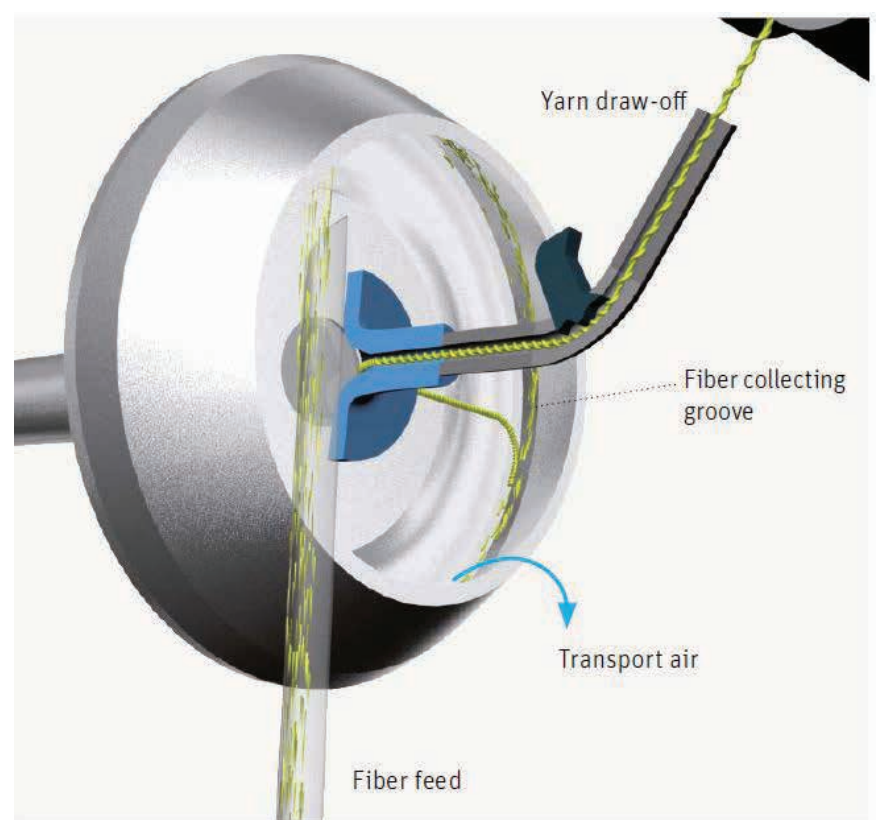

Figure 1. Tangential fiber feed into the rotor and fiber transport to the fiber collecting groove of the rotor [1].

by the interaction of the yarn and the spinning funnel leading the yarn out of the rotor. The latter, in turn, depends on the physical properties of the fibers (length, thinness, and friction), spinning speed, opening rollers with rigid clothing, etc. There are many companies involved in the production of rotor (openend) spinning machines. The leading manufacturers include companies such as Rieter, Schlafhorst, and Savio. One of the most modern rotor spinning frames is the FlexiRotors 300 from the Savio Company, equipped with, among others, a cleaningsplicing device, a tension compensator, as well as electronic control and electronic construction of the yarn packing. The rotor yarns are well suited for weaving and knitting purposes. Longer machines equipped with up to 320 spinning points are introduced. Smaller rotor diameters enable increasing their rotational speeds up to $150,000 \mathrm{rpm}[2,3]$. The rotor design technology can be defined as a property ensuring obtaining, at a given production volume, the required rotor properties with minimum production costs under given production conditions.

An important indicator of the constructionality of the structure is to provide the designed part (rotor) with the intended operational properties for it as low mass as possible. One of the ways leading to this is proper and rational selection of materials and forms of blanks for rotors. The selection of the semifinished product is an indispensable stage before starting to develop the process of manufacturing a given part. As a result, such approach allows for its detailed determination and accurate economic analysis, not only the cost of the material and labor but also the tooling cost associated with the technological method.

The issue of rational selection of material and the form of a semifinished product, usually due to one criterion, and most often the cost of production is discussed in a few papers [4-6]. However, there is practically no work in the field of multicriteria assessment and optimal selection of material and the form of

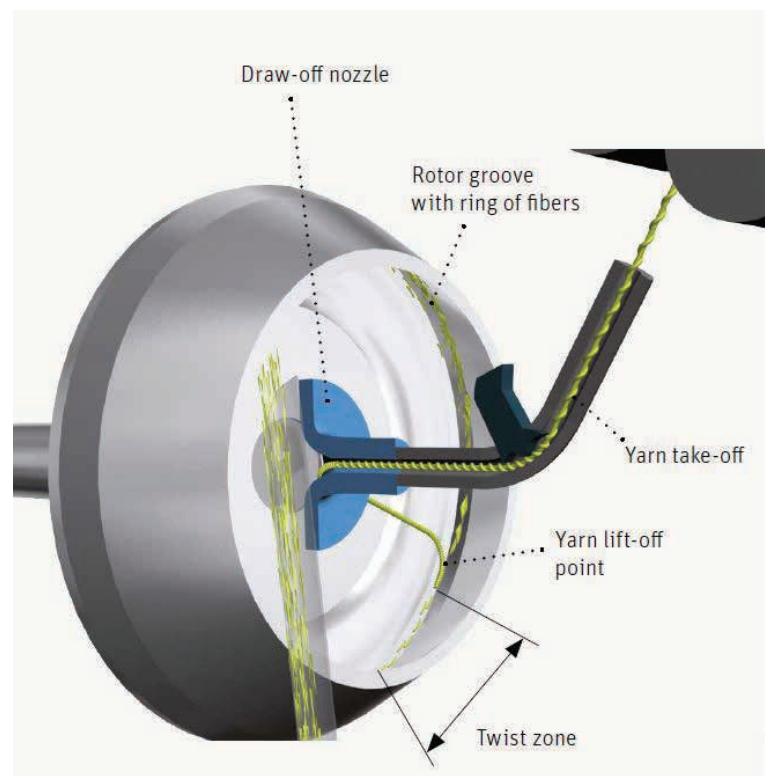

Figure 2. Yarn formation and twist insertion in the rotor groove [1].

a blank due to two or more criteria, for example the cost of production and the technological quality of the product.

The purpose of the work is to present the multicriteria evaluation procedure and its verification on the example of choosing the best material and form of a semifinished product, due to the unit cost of production and technological quality of the product, i.e. the index of material functionality and properties of the top layer of an open-end rotor spinning machine.

\section{Method of optimal selection of the material and the form of semi-product}

Issue of multicriteria assessment of design solutions and manufacturing processes has been presented, among others, in the following publications [7-14]. Multicriteria assessment and selection of the best material and form of semi-product are generally solved in two stages: determination of a set of optimal variants in Pareto sense and, next, selection of the best variant belonging to this set $[7,8,10,12]$.

\subsection{Pareto-optimum method}

To select optimal material and form of semi-product to production of the rotors, the Pareto-optimum method has been implemented, which consists in determination of the set of nondominated variants or set of optimal variants in Pareto sense $[8,12,13]$. Let $\boldsymbol{A}$ denote a permissible set of the materials and forms of semi-products:

$A=\left\{a_{1}, a_{2}, \ldots, a_{n}\right\}$

and $K^{(d)}-$ set of criteria with deterministic character from 1 to $m$ :

$K^{(d)}=\left\{k_{l}^{(d)}, k_{2}^{(d)}, \ldots, k_{m}^{(d)}\right\}$ 
Table with assessments of materials and semi-products due to individual criteria has the form of:

$$
\left[\begin{array}{l}
k_{11}^{(d)}, k_{12}^{(d)}, \ldots, k_{l i}^{(d)}, \ldots, k_{l s}^{(d)} \\
k_{21}^{(d)}, k_{22}^{(d)}, \ldots, k_{2 i}^{(d)}, \ldots, k_{2 s}^{(d)} \\
\ldots \ldots \ldots \ldots \ldots \ldots \ldots \ldots \ldots \ldots \ldots \ldots . \\
k_{j l}^{(d)}, k_{j 2}^{(d)}, \ldots, k_{j i}^{(d)}, \ldots, k_{j s}^{(d)} \\
\ldots \ldots \ldots \ldots \ldots \ldots \ldots \ldots \ldots \ldots \ldots \ldots . . \\
k_{m l}^{(d)}, k_{m 2}^{(d)}, \ldots, k_{m i}^{(d)}, \ldots, k_{m s}^{(d)}
\end{array}\right]
$$

where $k_{j i}^{(d)}=k_{j}^{(d)}\left(a_{i}\right)$ is the assessment of the $i$-th variant according to the $j$-th criterion, $j=1, \ldots, m$.

As ideal material and semi-product, it is considered as such a form (variant) that simultaneously extremizes each criterion.

In case of minimization, $a_{i}^{(i d)}$ is the material and ideal form of semi-product, when, for every $a_{i}$ belonging to the set $A$, such $a_{i}^{(i d)}$ exists (belonging to this set) that:

$$
\mathbf{k}^{(d)}\left(a_{i}^{(i d)}\right) \leq \mathbf{k}^{(d)}\left(a_{i}\right)
$$

where $\mathbf{k}^{(\alpha)}\left(a_{i}\right)$ is the vector of assessments of the $i$-th material and form of semi-product with respect to each from the criteria.

Because these criteria are usually conflicting, in such cases an ideal variant does not exist.

As non-dominated variant, it is considered such variant of the material and form of semi-product for which no criterion can be improved without simultaneous worsening at least one criterion from remaining criteria.

In case of minimization, $a_{i}^{(n d)}$ is non-dominated variant of the material and form of semi-product if, for every criterion $k_{j}^{(d)}$ it is not true that the vector of criteria $\mathbf{k}^{(\mathrm{d})}\left(a_{i}\right)$ exists (belonging to the set of criteria K) such that $k_{j}^{(d)}\left(a_{i}\right) \leq k_{j}^{(d)}\left(a_{i}^{(n d)}\right)$ as well as such criterion $k_{j}^{(d)}$ exists, which fulfills the condition $k_{j}^{(d)}\left(a_{i}^{(n d)}\right)<k_{j}^{(d)}\left(a_{i}\right)$.

The set of non-dominated variants $Z A$ is also called as set of Pareto-optimal variants. Set of the criteria-compromise assessments $Z K \in K^{(d)}$ is assigned to the set $Z A$.

Most often the set of Pareto-optimal variants contains many variants, and among them, based generally on additional criterion, the best variant (optimal variant) $a_{i}^{(o p t)} \in Z A$ is selected.

The variant $a_{i}^{(n d)}$ is considered as solution of the multicriteria assessment task in Pareto sense, when corresponding vector of the criteria $\mathbf{k}^{(d)}\left(a_{i}^{(n d)}\right)$ is the smallest vector in sense of partial arrangement.

In such formulation, it has been assumed that all the criteria need to be minimized. When the criterion $k_{j}^{(d)}\left(a_{j}\right)$ needs to be maximized in the multicriteria assessment task, such task can be reduced to the minimization task, changing sign of the criterion.

$$
\max _{j} k_{j i}^{(d)}=-\min _{j}\left(-k_{j i}^{(d)}\right)
$$

To assess the set of Pareto-optimal variants of material and form of semi-product, the specially developed POLOPT.2 program written in Pascal code has been implemented. The program enables, using conversation with computer, evaluation of the set of Pareto-optimal variants from the set of allowable variants consisting of maximum 100 variants, assessed maximally due to each of the 10 criteria. The program developed in such a way enables determination of a set of Pareto-optimal variants due to any number of criteria within interval from 2 to 10 .

The program is constructed from the following modules: creation of criteria set, reading of the criteria set, selection of the criteria to determination of Pareto set, determination of Pareto set, and sorting, viewing, and printing of Pareto set.

\subsection{Selection of the best solution with the use of distance function}

Methods of the distance function, in their classic approaches, enable determination of a single compromise assessment, which usually leads to designation of a single non-dominated variant. Lots of various criteria of the assessment, which characterize the variants, make that we deal with vector-type quality indicators. In a situation when some of these indicators are minimized, while the others are maximized, and bearing in mind the fact that majority of these indicators is expressed in a different units, problem of correct selection of the best variant becomes difficult [14]. To be independent of influence of different units of individual criteria, and bearing in mind that set of criteria includes assessments from which some assessments need to be minimized while the others maximized, it has been constructed the distance function $f_{\mu(i)}$ in the following form:

$f_{d(i)}=\sqrt{\sum_{j=1}^{m}\left[d_{i(j)}-d_{i d(j)}\right]^{2}} \rightarrow \min$

where $d_{i())}$ is the normalized value of $j$-th criterion for individual variants and $d_{i d(j)}$ is the normalized value of $j$-th for ideal point.

The best variant from set of Pareto-optimal variants is such a variant for which the distance function $f_{d(i)}$ reaches its minimal value.

\section{Example of selection of optimal variant of the material and form of semi-product for the rotor to open-end spinning frame}

Rotors in open-end spinning frames of PW12 type had operated with rotational speed from 300 to $400 \mathrm{rps}(18,000-24,000 \mathrm{rpm})$ and should comply with predetermined requirements concerning manufacturing quality, i.e., low roughness of internal surfaces $R a=0.08-0.16 \mu \mathrm{m}$, very low value of radial and axial runout of all faces and diameters above $40 \mathrm{~mm}-\Delta B \leq 0.050 \mathrm{~mm}$, and high durability. Moreover, dynamic balancing should be performed on the rotor assembled with elastic bearing and the 
race at rotational speed of $n=200 \mathrm{rps}$, while value of unbalance should not exceed $e_{r} \leq 0.05 \mu \mathrm{m}[13]$.

To perform optimal selection of the material and form of semiproduct for the rotor, at predetermined manufacturing cost and in terms of meeting high qualitative requirements, six brands of aluminum alloy in four forms of semi-product have been taken for the analysis: extruded rod, a forging, a casting, and rotor in assembled form (Table 1). The shape of the uniform rotor and the assembled rotor are presented in Figure 3.

In the set of allowable materials and forms of semi-product destined for the production of the rotors to open-end spinning frames, there are nine distinguished types, $a_{1}, a_{2}, a_{3}, a_{4}, a_{5}, a_{6}$, $a_{7}, a_{8}, a_{9}$, which are presented in Tables 1 and 2 .

For the above specified nine variants of materials and form of semi-products form the set of allowable variants, the manufacturing processes of the rotor have been designed, and the unit manufacturing costs have been evaluated.
Manufacturing processes of the rotors to open-end spinning frames are presented in the form of graph-tree (Figure 4) and described in Table 3.

Operation of hard anodic oxidation was foreseen to increase wear resistance and simultaneously to increase durability of the rotors in the manufacturing processes [13].

\subsection{Determination of the set of Pareto-optimal variants}

To determine set of Pareto-optimal variants the specially developed program POLOPT.2 written in Pascal code was implemented. Criteria to the assessment in this algorithm are treated as equally important (on equal right of importance). Using individual modules of this program, set of criteria for nine variants of the material and the form of semi-product for the rotor has been created. In the next step, the index max was assigned to the criteria when this criterion needs to be maximized in the task of multicriteria assessment, or min, if a
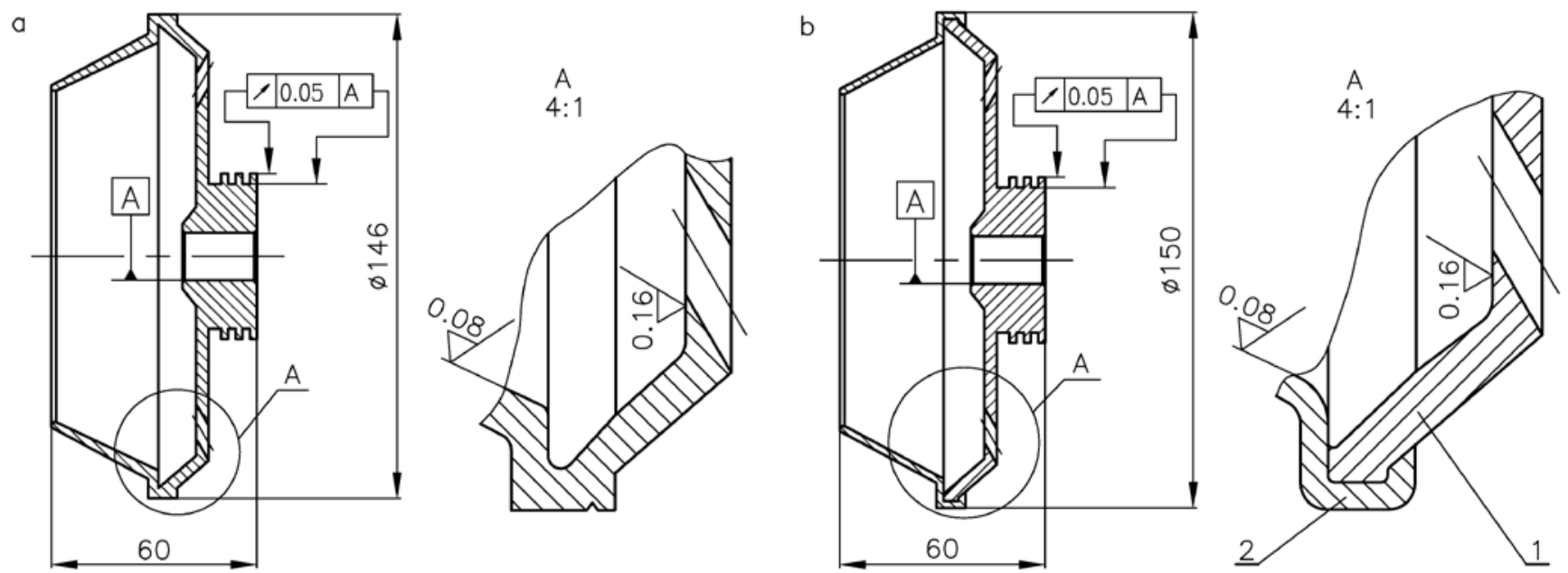

Figure 3. Rotor: (a) uniform, (b) assembled from two components: disk (1), spinned cone (2) from AIMg2.5 plate, connected in lapping operation [13].

Table 1. Characteristic of the materials and forms of semi-product for the rotors [13]

\begin{tabular}{|c|c|c|c|}
\hline $\begin{array}{c}\text { Numeric } \\
\text { denomination }\end{array}$ & Variants & $\begin{array}{c}\text { Marking with chemical } \\
\text { symbol }\end{array}$ & Form of semi-product \\
\hline EN AW-2024 & $a_{1}$ & AlCu4Mg1 & Extruded rod $\phi 150 \times 64.5 \mathrm{~mm}$ \\
\hline EN AW-6082 & $a_{2}$ & AlSi1MgMn & Extruded rod $\phi 150 \times 64.5 \mathrm{~mm}$ \\
\hline EN AW-2618A & $a_{3}$ & AlCu2Mg1,5Ni & Drop forging forged on hammer $\phi 155 \times 70 \mathrm{~mm}$ \\
\hline EN AW-2014 & $a_{4}$ & AlCu4SiMg & Drop forging forged on hammer $\phi 155 \times 70 \mathrm{~mm}$ \\
\hline EN AW-6082 & $a_{5}$ & AlSi1MgMn & Drop forging forged on hammer $\phi 155 \times 70 \mathrm{~mm}$ \\
\hline EN AW-45000 & $a_{6}$ & AlSi6Cu4 & Casting from sand mold $\phi 153 \times 91 \mathrm{~mm}$ \\
\hline EN AW-71xxx & $a_{7}$ & AlZn9Si7 & Casting from sand mold $\phi 153 \times 91 \mathrm{~mm}$ \\
\hline $\begin{array}{l}\text { EN AW-2024 } \\
\text { EN AW-5052 }\end{array}$ & $a_{8}$ & $\begin{array}{l}\text { AlCu4Mg1 } \\
\text { AlMg2.5 }\end{array}$ & $\begin{array}{c}\text { Disk produced from extruded rod } \phi 155 \times 33 \mathrm{~mm} \text {, while the cone from } \\
\text { metal plate with dimensions } 195 \times 195 \times 2 \mathrm{~mm}\end{array}$ \\
\hline $\begin{array}{l}\text { EN AW-2618A } \\
\text { EN AW-5052 }\end{array}$ & $a_{9}$ & $\begin{array}{l}\text { AlCu2Mg1,5Ni } \\
\quad \text { AIMg2.5 }\end{array}$ & $\begin{array}{l}\text { Disk produced from drop forging } \phi 155 \times 38 \mathrm{~mm} \text {, while the cone from } \\
\text { metal plate with dimensions } 195 \times 195 \times 2 \mathrm{~mm}\end{array}$ \\
\hline
\end{tabular}


Table 2. Characteristic of the materials and forms of semi-product for the rotors [13]

\begin{tabular}{|c|c|}
\hline Variants $a_{1}, a_{2}$ & $\begin{array}{l}\text { Rotors from these variants were made from semi-product in the form of extruded rod from aluminum } \\
\text { alloy } A / C u 4 M g 1 \text {, i.e. in naturally precipitation hardened state (ta) and extruded rod from aluminum alloy } \\
\qquad A / S i 1 M g M n \text { in artificially precipitation hardened state (tb) }\end{array}$ \\
\hline Variants $a_{3}, a_{4}, a_{5}$ & $\begin{array}{l}\text { Rotors from these variants were made from semi-product in the form of drop forgings from aluminum } \\
\text { alloys AICu2Mg1,5Ni; AlCu4SiMg; and AISi1MgMn forged on hammer, and next artificially precipitation } \\
\text { hardened (tb) }\end{array}$ \\
\hline Variants $a_{6}, a_{7}$ & $\begin{array}{l}\text { Rotors from these variants were made from semi-product in the form of casting from sand mold from } \\
\text { aluminum alloys AlSi6Cu4 and AlZn9Si7 }\end{array}$ \\
\hline Variants $a_{7}, a_{9}$ & $\begin{array}{l}\text { Rotors from these variants were made as assembled from two elements: disk and cone; the disk was } \\
\text { produced in turning operation from extruded rod from aluminum alloy } A / C u 4 M g 1 \text { (variant } a_{8} \text { ) and drop } \\
\text { forged from aluminum alloy } A / C u 2 M g 1,5 N \text { forged on hammer (variant } a_{9} \text { ) whereas the cone in the both } \\
\text { variants was spinned on the mandrel from metal sheet } A / M g 2,5 \text { to thickness } 2 \mathrm{~mm}\end{array}$ \\
\hline
\end{tabular}

given criterion should be minimized in the task of multicriteria assessment.

To assess the variants, one used the unit manufacturing cost and three criteria of technological quality of the rotor:

- unit manufacturing cost $K_{w}(E U R / p i e c e)$,

- index of functionality of the material $\sigma_{f} / \rho(\mathrm{Nm} / \mathrm{kg})$,

- $\quad$ maximum height of the surface peaks $S p(\mu \mathrm{m})$, and

- maximal hardness on surface of oxide layer $\mu H V_{0,1}(\mathrm{MPa})$.

Computations of the unit manufacturing costs for different materials and forms of semi-product to production of the rotors to open-end spinning frames were based on the algorithm of multistage additional calculation, according to the costs of the workplace described in the publications $[15,16]$.

Selection of the material for the rotor, without taking into account the shape of cross section, was performed according to criterion of maximization of functionality index of the material, defined in case of rotating parts as a ratio of destructive stress $\sigma_{f}$ to specific mass $\rho$ [4]. To evaluate the functionality index of the material $\sigma_{f} / \rho$, values of the yield strength $R p_{02}$ (for aluminum alloys destined to plastic forming) and tensile strength Rm (for casting aluminium alloys) and specific mass (density) for aluminium alloys taken to the analysis were read from the publications [17-19].

Investigations of the technological quality were performed on samples with dimensions $\varnothing 22^{+0,10} \times 40 \mathrm{~mm}$ produced from investigated aluminum alloys in the form of extruded rod, a forging, and a casting. In the next step, the samples were turned, grinded with abrasive cloth with grain size of 150 and 220 , and polished with felt buffing wheel impregnated with abrasive compound of Z-50 brand. Prepared in such a way, samples were subjected to operation of hard electrolytic oxidation [13], which was performed in solution of electrolyte having the following composition (by weight): sulfurous acid$6 \%$, sulfosalicylic acid-3\%, lactic acid-2\%, glycerol-2\%, aluminum sulfate- $0.1 \%$, and distilled water as remaining content. Conditions of the electrolytic oxidation were as follows: direct current + alternating current, including portion of positive component of $85 \%$, anodic current density $6 \mathrm{~A} / \mathrm{dm}^{2}$, temperature of the electrolyte from $-2^{\circ \circ} \mathrm{C}$ to $+6^{\circ} \mathrm{C}$, and time required for oxidation $40 \mathrm{~min}$. Prior to the electrolytic oxidation, the surfaces destined to the oxidation were degreased in organic solvent and etched in $5 \%$ solution of sodium hydroxide for $2 \mathrm{~min}$ and in the next step were rinsed in water.

Measurements of the selected geometrical structure parameters of the surface (SGP 3D) were performed on specially prepared samples having dimensions $\varnothing 22^{+0,10} \times 40 \mathrm{~mm}$ with the use of the Perthometer Concept V.700 profilometer produced by Mahr Company with measuring probe having shape of cone and $r_{o s}=2 \mu \mathrm{m}$ fillet radius of the gauging edge. The measurements were performed on the surface area of $2.0 \mathrm{~mm} \times 2.0 \mathrm{~mm}$ after production of 401 parallel sections spaced every $5 \mathrm{~mm}$, at measuring load $0.75 \mathrm{mN}$, with feedrate of gauging point's edge $0.5 \mathrm{~mm} / \mathrm{s}$, sampling step $0.20 \mu \mathrm{m}$, sampling length $0.4 \mathrm{~mm}$, and measuring length $5 \times 0.4 \mathrm{~mm}=2.0 \mathrm{~mm}$. One measured the following $3 D$ parameters of surface roughness of the oxide layer: amplitude parameters-mean arithmetical of the surface ordinates $\mathrm{Sa}$, mean square deviation of the surface $\mathrm{Sq}$, maximum height of the surface peaks $S p$, the maximum depth of the surface cavities $S v$, maximum height of the surface $S t$, parameters of the surface curve of the material part, depth of the surface core $S k$, reduced height of the surface peaks Spk, reduced depth of the surface cavities Svk, load capacity part of the surface peaks Smr1, and load capacity part of the surface cavities Smr2 [20].

Selected roughness parameters of 3D surface of the aluminum alloys before the hard electrolytic oxidation operation were included in the following range: $S a=0.15 \div 0.25 \mu \mathrm{m}$, $S q=0.20 \times 0.35 \mu \mathrm{m}$, and $S p=0.95 \div 2.50 \mu \mathrm{m}$, whereas after electrolytic oxidation was performed the parameters were $\mathrm{Sa}=0.69 \div 4.38 \mu \mathrm{m}, \mathrm{Sq}=0.92 \div 5.37 \mu \mathrm{m}$, and $S p=3.51 \div 17.10 \mu \mathrm{m}$.

The Sp parameter was taken in the assessment of 3D surface roughness because of the rewinding speed of $90 \mathrm{~m} / \mathrm{min}$ and 
Table 3. Description of the graph-tree with variants of manufacturing process of the rotor

\begin{tabular}{|c|c|c|}
\hline $\begin{array}{l}\text { No. } \\
\text { oper. }\end{array}$ & Type of the operation & Workstation \\
\hline 10 & Cutting the material to dimension " $x$ " & Band-saw SBA421/S \\
\hline 20 & Turning the external surfaces and drilling the hole $\phi 11$ & $\begin{array}{l}\text { CNC turning lathe } \\
\text { Okuma LB 25II-C }\end{array}$ \\
\hline 30 & $\begin{array}{l}\text { Drilling the hole } \phi 50 \text {, turning the external surfaces, turning the internal } \\
\text { surfaces, and boring the recess and collective groove. Boring the hole } \\
\qquad 12 \text { and reaming the hole to } \phi 12.2 \cup 7\end{array}$ & $\begin{array}{l}\text { In the next step one determined Pareto-optimal } \\
\text { set for allowable variants, consisting of nine } \\
\text { variants of the material and the form of semi- } \\
\text { product for the rotor Okuma LB 25II-C }\end{array}$ \\
\hline 40 & Turning the hub to $\phi 47$ and grooves, width $2.5 \mathrm{~mm}$ & Turning lathe TUG-56MN \\
\hline 45 & $\begin{array}{l}\text { Finish turning the external surfaces, boring the internal surfaces, and } \\
\text { spot facing the collective groove }\end{array}$ & $\begin{array}{l}\text { CNC turning lathe } \\
\text { Okuma LB 25II-C }\end{array}$ \\
\hline 50 & $\begin{array}{c}\text { Finish turning the external surface and boring the internal conical } \\
\text { surface together with collective groove }\end{array}$ & $\begin{array}{l}\text { CNC turning lathe } \\
\text { Okuma LB 25II-C }\end{array}$ \\
\hline 60 & Inter-operational control & Claw fixture and sensing element \\
\hline 70 & Drilling of 12 holes $\phi 6$ & Drilling machine $2 \mathrm{H}-125$ \\
\hline 80 & Blunting the sharp edges & Grinding station \\
\hline 90 & Grinding with abrasive cloth having grain size 150 and 220 & Special grinder \\
\hline 100 & Polishing with felt disk saturated with polishing compound Z-50 & Polisher \\
\hline 110 & Electrolytic oxidizing & Stand to electrolytic oxidation \\
\hline 120 & Dynamic balancing & Dynamical balancer \\
\hline 130 & Final control & Control-measuring station \\
\hline 140 & $\begin{array}{l}\begin{array}{l}\text { Turning the face and external diameter of hub and face of the hub, } \\
\text { drilling the hole } \phi 11\end{array}\end{array}$ & $\begin{array}{l}\text { CNC turning lathe } \\
\text { Okuma LB25II-C }\end{array}$ \\
\hline 150 & $\begin{array}{l}\text { Rough boring and shaping the external surface, spot facing the face, } \\
\text { rough boring and shaping the internal surface of the hole, turning } \\
\text { the collective groove and remaining external surfaces, boring the } \\
\text { hole } \phi 102, \text { finish boring the internal cone with collective groove, and } \\
\text { chamfering and boring the hole } \phi 12,2 \cup 7\end{array}$ & $\begin{array}{l}\text { CNC turning lathe } \\
\text { Okuma LB 25II-C }\end{array}$ \\
\hline 160 & $\begin{array}{l}\text { Cutting-off the feedhead, drilling the hole } \phi 11 \text {, reaming the hoe to } \phi 12,2 \\
\text { U7, and turning the external diameter of the hub and facing face of the } \\
\text { hub }\end{array}$ & $\begin{array}{l}\text { CNC turning lathe } \\
\text { Okuma LB 25II-C }\end{array}$ \\
\hline 170 & $\begin{array}{l}\text { Boring the internal surface with collective groove, turning the external } \\
\text { surface, and finish boring the internal surfaces and collective groove }\end{array}$ & $\begin{array}{l}\text { CNC turning lathe } \\
\text { Okuma LB 25II-C }\end{array}$ \\
\hline 180 & $\begin{array}{l}\text { Preliminary turning the hub, turning the cone, spot drilling with stiff drill } \\
\qquad \phi 20 \text {, drilling the hole } \phi 11 \text {, turning the hub }\end{array}$ & $\begin{array}{l}\text { CNC turning lathe } \\
\text { Okuma LB 25II-C }\end{array}$ \\
\hline 190 & $\begin{array}{l}\text { Facing the face, turning the internal surface with recess, turning the } \\
\text { collective groove, reaming the hole } \phi 12.2 \mathrm{U} 7 \text {, chamfering the hole }\end{array}$ & $\begin{array}{l}\text { CNC turning lathe } \\
\text { Okuma LB 25II-C }\end{array}$ \\
\hline 200 & Turning external surface of the hub and disk, turning the grooves & $\begin{array}{l}\text { CNC turning lathe } \\
\text { Okuma LB 25II-C }\end{array}$ \\
\hline 210 & Grinding with abrasive cloth having grain size 150 and 220 & Special grinder \\
\hline 220 & $\begin{array}{l}\text { Polishing internal surface of the disk with felt disk saturated with } \\
\text { polishing compound Z-50 }\end{array}$ & Special polisher \\
\hline 230 & $\begin{array}{l}\text { Cutting metal sheet from aluminum alloy AlMg2,5 thickness } 2 \mathrm{~mm} \text {, to } \\
\text { dimension } 195 \times 195 \mathrm{~mm}\end{array}$ & Mechanical guillotine Q11 $2 \square 2,000$ \\
\hline 240 & $\begin{array}{l}\text { Laying-off the hole, drilling the hole } \phi 6, \text { blunting sharp edges, turning } \\
\text { the disk to dimension } \phi 188 \text {, blunting the edges }\end{array}$ & Drilling machine $2 \mathrm{H}-125$ \\
\hline 250 & Grinding the disk with abrasive paper having grain size 220 & Special grinder \\
\hline 260 & Polishing cut-off disk $\phi 188 \times 2 \mathrm{~mm}$ with polishing compound Z-50 & Special grinder \\
\hline 270 & Attaching on the core and spinning & Turning lathe TUG-56MN \\
\hline 280 & Attaching on the core, cutting-off the flange and bottom of the cone & Turning lathe TUG-56MN \\
\hline 290 & Lapping of the border of the cone on the disk & Turning lathe TUG-56MN \\
\hline 300 & Facing the face of cone, boring the hole $\phi 102 \pm 0.2$ & Turning lathe TUG-56MN \\
\hline 310 & $\begin{array}{l}\text { Facing the face of the disk, turning face of the disk, turning the hub, } \\
\text { boring with stiff drill } \phi 20 \text {, drilling the hole } \phi 11 \text {, and chamfering the hole }\end{array}$ & $\begin{array}{l}\text { CNC turning lathe } \\
\text { Okuma LB } 25 I I-C\end{array}$ \\
\hline 320 & $\begin{array}{l}\text { Facing the face, turning the external surface, turning the recesses, } \\
\text { turning the collective groove, and reaming the hole } \phi 12.2 \cup 7\end{array}$ & $\begin{array}{l}\text { CNC turning lathe } \\
\text { Okuma LB 25II-C }\end{array}$ \\
\hline
\end{tabular}




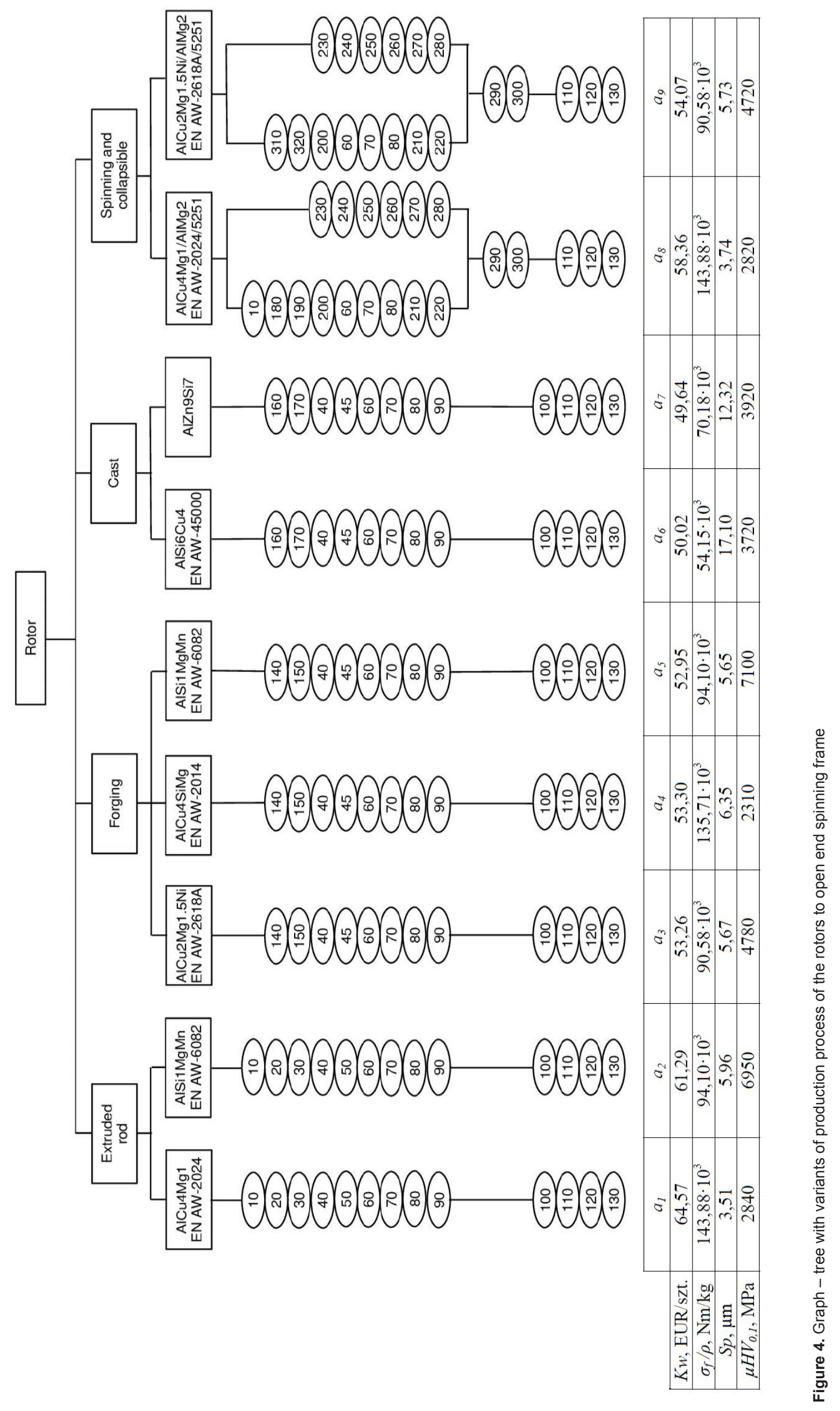


Table 4. Pareto-optimal set for four criteria: $K w, \sigma_{f} / \rho, S_{p}, \mu H V_{0,1}$

\begin{tabular}{|c|c|c|c|c|c|}
\hline Ordinal number & No. of variants & $K w(E U R / p i e c e)$ & $\sigma_{f} / \rho(\mathrm{Nm} / \mathrm{kg})$ & $S_{p}(\mu \mathrm{m})$ & $\mu H V_{0,1}(\mathrm{MPa})$ \\
\hline 1 & $a_{1}$ & 64,57 & $143.88 \cdot 10^{3}$ & 3.51 & 2,840 \\
\hline 2 & $a_{4}$ & 53,30 & $135.71 \cdot 10^{3}$ & 6.35 & 2,310 \\
\hline 3 & $a_{5}$ & 52.95 & $94.10 \cdot 10^{3}$ & 5.65 & 7,100 \\
\hline 4 & $a_{7}$ & 49.64 & $70.18 \cdot 10^{3}$ & 12.32 & 3,920 \\
\hline 5 & $a_{8}$ & 58.36 & $143.88 \cdot 10^{3}$ & 3.74 & 2,820 \\
\hline
\end{tabular}

Table 5. Normalized values of the criteria $d_{i(\hat{)})}$ from Pareto-optimal set

\begin{tabular}{|c|c|c|c|c|c|}
\hline Ordinal number & No. of variant & $K w(E U R / p i e c e)$ & $\sigma_{f} / \boldsymbol{\rho}(\mathbf{N m} / \mathbf{k g})$ & $\boldsymbol{S}_{p}(\boldsymbol{\mu m})$ & $\mu H V_{0,1}(\mathrm{MPa})$ \\
\hline 1 & $a_{1}$ & 1.000000 & 1.000000 & 0.000000 & 0.110647 \\
\hline 2 & $a_{4}$ & 0.245144 & 0.889145 & 0.322361 & 0.000000 \\
\hline 3 & $a_{5}$ & 0.221701 & 0.324559 & 0.242906 & 1.000000 \\
\hline 4 & $a_{7}$ & 0.000000 & 0.000000 & 1.000000 & 0.336117 \\
\hline 5 & $a_{8}$ & 0.584059 & 1.000000 & 0.026107 & 0.106472 \\
\hline
\end{tabular}

above, and the value of the coefficient of determination $R^{2}$ between this parameter and coefficient of kinetic friction $\mu_{k}$ of the yarn against electrolytically oxidized surface was the highest $-R^{2}=0.9936$ [21].

To assess the physical properties of the surface layer, only the maximal hardness $\mu H V_{0,1}$ has been taken. Because of this, in the result of many years' observations and investigations performed in industrial conditions on components of the openend spinning frames, it has been ascertained that together with increasing hardness of the oxidized surfaces being in direct contact with yarn, wear of such components is strongly decreasing (coefficient of linear correlation $R=0.9457$ ). However, the thickness of oxidized layer $g_{p}$ after hard electrolytic oxidation, in case of the investigated alloys, fluctuated in the range of $80 \div 100 \mu \mathrm{m}$, and its effect on the wear was distinctly lower [13]. For this reason, thickness of the oxidized layer $g_{p}$ was neglected in the assessment of materials and the forms of semi-product. In-depth measurements of hardness distribution of the oxidized layer $\mu H V_{0,1}=f\left(g_{p}\right)$ of the samples were performed using Vickers method on microsections skewed at angle $1^{\circ} 30^{\prime}(0.026 \mathrm{rad})$, under the load of micro-indenter of $0.98 \mathrm{~N}$ with use of the Leitz Wetzlar microhardness tester. At least trifold repeatability was used during the measurements of the hardness. To eliminate gross errors, all measurement results were verified for statistic homogeneity, making use of the Grubbs test. Critical value of test function $T_{k r}$ was read from Table 5 [22] depending on the number of the tests $n_{p r}=5$ and the number of repetitions $n_{p}=3$, and the significance level was assumed as $\alpha=0.05$ (5\%). After elimination of the gross errors, average values were computated for individual criteria of the assessment; computated values were specified in Figure 4.

In the next step of the proceeding, the Pareto-optimal set was determined for the analyzed set of allowable variants, consisting of nine variants of the materials and the forms of semi-product for the rotor. Pareto-optimal set for four criteria include unit manufacturing cost $K w$, functionality index of the material $\sigma_{f} / \rho$, roughness of 3D surface described by parameter $S_{p}$, and the maximal microhardness $\mu H V_{0,1}$ consisting of five variants. Optimal variants in Pareto sense are the following: $a_{1}$, $a_{4}, a_{5}, a_{7}$ and $a_{8}$ (Table 4).

\subsection{Selection of the best variant using the distance function}

In the next stage of the proceeding, deterministic values of the assessment criteria for the Pareto-optimal set were reduced to the interval $<0 ; 1>$ making use of the following normalization function:

$$
d_{i(j)}=\begin{gathered}
k_{i j}-\min _{1 \leq l \leq n}\left(k_{l j}\right) \\
{\left[\max _{1 \leq l \leq n}\left(k_{l j}\right)-\min _{1 \leq l \leq n}\left(k_{l j}\right)\right]}
\end{gathered}
$$

In result of the normalization, the following values of the criteria from the interval $<0 ; 1>$ for the individual variants, constituting the Pareto-optimal set (Table 5) have been obtained.

Coordinates of the ideal point were determined in the next stage, considering that a criterion needs to be minimized or maximized in the task:

$$
d_{i d(j)}=(0 ; 1 ; 0 ; 1)
$$

To select the best variant from the Pareto-optimal set, the distance function described by the formula (6) has been used. In case of four criteria, shape of this function is as follows:

$$
f_{d(i)}=\sqrt{\left[d_{i(1)}-d_{i d(1)}\right]^{2}+\left[d_{i(2)}-d_{i d(2)}\right]^{2}+, \ldots,+\left[d_{i(4)}-d_{i d(4)}\right]^{2}}
$$

Value of the distance function $f_{d(i)}$ for 5 Pareto-optimal variants is presented in the Table 6 . 
Table 6. Value of the distance function $f_{d(i)}$ for 5 Pareto-optimal variants

\begin{tabular}{|c|c|c|}
\hline No. & Number of variant & Distance from ideal variant \\
\hline 1 & $a_{1}$ & 1.338263 \\
\hline 2 & $a_{4}$ & 1.084574 \\
\hline 3 & $a_{5}$ & 0.751249 \\
\hline 4 & $a_{7}$ & 1.562289 \\
\hline 5 & $a_{8}$ & 1.067801 \\
\hline
\end{tabular}

As the best variant was chosen, the value of the distance function $f_{d(i)}$ is the lowest. In our case, the best variant is $a_{5}$, i.e. EN AW-6082 (AISi1MgMn) aluminium alloy in the form of forging forged on hammer (low series production), and in the next operation artificially hardened during precipitation treatment of artificial age hardening (tb), for which $f_{d(a 5)}=0.751249$. For the optimal variant, the values of the criteria are as follows: $K_{w}=52.95 \mathrm{EUR} / \mathrm{pcs} ; \sigma_{f} / \rho=94.10 \times 10^{3} \mathrm{Nm} / \mathrm{kg} ; \mathrm{Sp}=5.65 \mu \mathrm{m}$; $\mu H V_{0,1}=7,100 \mathrm{MPa}$.

\section{Conclusions}

Based on the analysis of the literature review and own research, it can be concluded that:

1. In situations when we can determine the values of the criteria taken for the assessment with sufficient accuracy, two-stage procedure of multicriteria optimization due to two or more criteria to the assessment, can bring good results in selecting the best variant of a material and the form of a semi-product for components of textile machines, being in contact with yarn or fiber.

2. In the first stage, this procedure comprises determination of the set of Pareto-optimal variants (set of non-dominated variants), whereas in the second stage, selection of the best variant from this set using the distance function.

3. Advantage of this procedure is that the same criteria of the assessment are used in both the stages of optimization proceeding. It is therefore not necessary to determine an additional (the most often new) criterion, which makes choosing the optimal solution much easier.

4. In the case of rotors that are an integral part of open-end rotor spinners, the optimal material is an aluminum-siliconmagnesium-manganese alloy with the symbol EN AW6082 (AlSi1MgMn) characterized by the lowest specific mass and a high yield strength and ensuring the highest hardness due to electrolytic oxidation of the oxide layer.

5. For larger rotor diameters, the best form of the semifinished product is forging in a state of artificial hardening, which ensures a relatively low unit cost of production.

\section{References}

[1] The Rieter Maual of Spinning, Volume 5 - Rotor spinning ISBN 10 3-9523173-5-7, ISBN 13 978-3-95223173-5-8, pp. 24-25, 2020. Web site January, 21,2020. Web site: http://www.rieter.com

[2] Lawrnce, C. A. (2003). Fundamentals of spun yarn technology. CRC Press (Leeds).

[3] Heinz, E. (2016). The rieter manual of spinning. Rotor Spinning, Vol. 5. Rieter Machine Works Ltd. Web site: www.rieter.com

[4] Ashby, M. F. (1998). Selection of materials in engineering design. WNT (Warszawa).

[5] Feld, M. (2008). Fundamentals of development of technological processes of typical machinery components. Wydawnictwo Naukowe PWN (Warszawa).

[6] Siecla, R. (1992). Selection of semi-products in aided design of a technological process. Presentation for the objects from "rotating parts" group. Zeszyty Naukowe Politechniki Poznańskiej 37, Mechanika, 1992, 91-98.

[7] Eschenauer, H., Koski, J., Osyczka, A. (1990). Multicriteria design optimization. Springer-Verlag (Berlin).

[8] Montusiewicz, J. (2004). Evolutionary multicriteria optimization in technical issues. IPPT PAN (Warszawa).

[9] Breiing, A., Knosala, R. (1997). Bewerten technischen Systeme (Theoretische und methodische grundlagen bewertungstechnischer Entscheidungshilfen). SpringerVerlag (Berlin-Heidelberg).

[10] Szadkowski, J. (1982). Methodological problems of poliooptimization in mechanical engineering. Materiały XXI Sympozjum "Modelowanie w Mechanice". PTMTS, Gliwice - Wisła, 1982.

[11] Szadkowski, J. (1992). Artificial intelligence approach to structural and parametrical optimization of multi-toolmachining processes. Gepgyartastechnologia, Budapest, 9-10, 1992.

[12] Szadkowski, J., Płonka, S. (1990). Machining process optimization considering wear resistance of manufactured elements. Materiały III Międzynarodowego Sympozjum INSYCONT. IPBM AGH i SEM KBM PAN, Kraków, 1990.

[13] Płonka, S. (1998). Methods of assessment and selection of optimal structure of technological process. Rozprawy naukowe 48. Budowa i eksploatacja maszyn. Politechnika Łódzka Filia w Bielsku-Białej, 1998.

[14] Płonka, S. (2017). Multicriteria optimization of manufacturing processes of machinery elements. WNT (Warszawa).

[15] Matuszek, J., Kłosowski, M., Krokosz-krynke, Z. (2011). Cost accounting for engineers. PWE (Warszawa).

[16] Więcek, D., Więcek, D. (2018). Production costs of machine elements estimated in the design phase. Advances in Intelligent Systems and Computing, 637(2018), 380-391. Springer (Cham).

[17] Dobrzański, L. A., Sitek, W., Trzaska, J., Gołombek, K., Hajduczek, E. (2001). Principles of selection of engineering materials. Wyd. II. Wydawnictwo Politechniki Śląskiej (Gliwice).

[18] Oczoś, K. E., Kawalec, A. (2012). Forming of light metals. Wydawnictwo Naukowe PWN (Warszawa). 
[19] PN-EN 755-2: 2016-05 -Aluminum and aluminum alloysRods, pipes and extruded sections. Part II: Mechanical properties.

[20] ISO 25178-2:2012(E) - Geometrical product specifications (GPS) - Surface texture: Areal - Part 2: terms, definitions and surface texture parameters.

[21] Płonka, S., Przybyło, S. (2007). Effect of the 3D surface structure of oxide coating on the kinetic friction coefficient. Tribologia, 38(6), 151-163.

[22] Zieliński, W., Zieliński, R. (1990). Statistic tables. PWN (Warszawa). 